\title{
Evaluation of Immunostimulant Activity and Inhibition of Cytokine Storm Activity of Proprietary Herbal Formulation Virulina ${ }^{\circledR}$
}

\author{
Sandeep Arora 1,* (D), Anil Sharma ${ }^{2} \mathbb{D}$, Neelam Sharma ${ }^{1} \mathbb{D}$, Sukhbir Singh ${ }^{1}$ (D), Thakur Gurjeet \\ Singh 1 iD \\ 1 Chitkara College of Pharmacy, Chitkara University, Punjab, India \\ 2 Natural Solutions, Mumbai \\ * Correspondence: sandeep.arora@chitkara.edu.in;
}

Scopus Author ID 42060889400

Received: 28.09.2020; Revised: 27.10.2020; Accepted: 29.10.2020; Published: 31.10.2020

\begin{abstract}
Immunostimulation is the strengthening of the immune system through the induction of nonspecific immune responses. Synthetic drugs have harmful side effects, enormous costs, and are ineffectual in controlling several pathological disorders. Therefore, nowadays, herbal immunostimulants have been considered as a superior and less toxic opportunity for the management of disorders as well as their complications. The objective of the current investigation is the formulation of Virulina ${ }^{\circledR}$-Natural Solutions $\left(\mathrm{VL}^{\circledR}-\mathrm{NS}\right)$ polyherbal formulation and its evaluation for immunostimulant and cytokine storm inhibition activity. The immunostimulant \& anti-inflammatory potential of Virulina ${ }^{\circledR}$ were determined by using in-vitro phagocytosis through polymorphonuclear analysis, indicating the invasion of leukocytes. In-vitro cytokine storm inhibitory activity was also performed using mouse macrophage cells (RAW264.7) treated with polyinosinic-polycytidylic acid to test the ability of Virulina ${ }^{\circledR}$ to attenuate the immune responses. The inflammatory responses were evaluated by the endotoxin-lipopolysaccharide (LPS) model following the endotoxin challenges of aggravating the inflammatory mediators (cytokines); thereby, the LPS derived from E. coli as antigen at a dose of $10 \mathrm{mgkg}^{-1}$, i.p was used for the systemic inflammation. $\mathrm{VL}^{\circledR}$-NS exhibited enhanced phagocytic efficacy at $100 \mathrm{mgml}^{-1}$ in PMN function test. $\mathrm{VL}^{\circledR}$-NS significantly decreases the expression of a cytokine such as interleukin-6, tumor necrosis factor- $\alpha$ \& vascular endothelial growth factor in RAW264.7 cell culture. The increase in LPS-induced cytokine levels in rat serum was dose-dependently \& significantly $(\mathrm{p}<0.05)$ inhibited by VL®-NS treatment. VL ${ }^{\circledR}$-NS tend to be potent immunostimulant therapy as a superior and less toxic opportunity for the strengthening of the immune system for the management of several inflammatory disorders.
\end{abstract}

Keywords: Immunostimulant; polyherbal formulation; phagocytosis; polymorphonuclear analysis; cytokine storm inhibitory activity; interleukin- 6 , tumor necrosis factor- $\alpha$.

(C) 2020 by the authors. This article is an open-access article distributed under the terms and conditions of the Creative Commons Attribution (CC BY) license (https://creativecommons.org/licenses/by/4.0/).

\section{Introduction}

Immunotherapy is a revolutionizing treatment paradigm for the advanced therapeutic approach of immunodeficiency diseases nowadays. Recently, the current scenario of the research is employed in the designing of immunostimulatory formulation to induce the adjuvant immune response for better tolerance of the immunodeficiency conditions like respiratory tract infections, chronic obstructive pulmonary disease, diabetes, and cancer. The herbal medicinal plants as a natural source of therapeutic aid in improving the immune system 
and the various herbal plants have gained significant attention in the research of polyherbal formulation as adjuvant enhancement of the immune system. Therefore, herbal immunostimulants have been considered as superior and less toxic opportunities for the management of disorders, as well as their complications [1-12]. Although the advancement in the field of synthetic medicines in the management of immunodeficiency disorders but due to the numerous reported harmful side effects and enormous cost-related problems with synthetic medicines, the alternative, complementary therapy have replaced the synthetic treatment with natural herbal medicines tends to patient compliance with lesser side effects and low medication adherence. The literature supports traditional herbal treatment or folklore medicines used in the treatment of enhancing the immune system including plants like Emblica officinalis [13], Terminalia chebula [14], Berberis Aristata [15], Solanum xanthocarpum [16], Zingiber officinale [17], Marshdenia Tenacissima [18], Tinospora Cordifolia [19], Alhagi Maurorum [20], Picrorhiza kurroa [21], Azadirachta indica [22], Glycrrhiza glabra [23], Trachyspermum ammi [24], Clerodendrum serratum [25], Cedrus deodara [26], Andrgraphis paniculata [27], Syzigium aromaticum [28], Cinnamomum tamala [29], Myristica fragrans [30], Aconitum heterophyllum [30], Curcuma longa [32], Santalum album [33] and Sida cordifolia [34], Desmodium gangeticum [35]. These plants tend to possess active phytoconstituents having anti-oxidant, anti-inflammatory, and immunomodulatory effects. The current research investigated the polyhedral formulation Virulina ${ }^{\circledR}-N a t u r a l$ Solutions $\left(V^{\circledR}{ }^{\circledR}-N S\right.$ ) as a combination of several immunostimulant herbs designed by using the standard powder formulation method (Table 1) likely to be an effective therapy in improving the immune system. VL ${ }^{\circledR}-\mathrm{NS}$ was assessed for phagocytosis through in-vitro polymorphonuclear (PMN) function test. The in-vitro cytokine storm inhibitory activity of $\mathrm{VL}^{\circledR}$-NS was assessed in mouse mononuclear macrophage leukemia cells and in-vivo pharmacological activity was performed in rats through induction of lipopolysaccharide mediated cytokine storm activity. Therefore, the current study provides new research of $\left(\mathrm{VL}^{\circledR}-\mathrm{NS}\right)$ polyherbal formulation comprising traditional herbal plants listed in table 1 having active phytoconstituents possessing antioxidant, anti-inflammatory activity and tends to modify the immune system for management of several inflammatory disorders.

Table 1. Composition of proprietary herbal formulation Virulina®-Natural Solutions.

\begin{tabular}{|c|c|c|c|}
\hline Dravya & Scientific name & Part used & Amount (mg) \\
\hline $\begin{array}{l}\text { Triphala (Amla, Harde \& } \\
\text { Baheda) }\end{array}$ & $\begin{array}{l}\text { Emblica officinalis, Terminalia chebula, } \\
\text { Terminalia bellirica }\end{array}$ & Fruit & 50 \\
\hline Daruharidra & Berberis aristata & Fruit and stem & 50 \\
\hline Kantakari & Solanum xanthocarpum & Root and fruit & 100 \\
\hline $\begin{array}{l}\text { Trikatu (Sunthi, Maricha, } \\
\text { Pippali) }\end{array}$ & $\begin{array}{l}\text { Zingiber officinale, Piper nigrum, Piper } \\
\text { longum }\end{array}$ & Root & 100 \\
\hline Moorba & Marsdenia tenacissima & Root & 50 \\
\hline Guduchi & Tinospora cordifolia & Stem & 100 \\
\hline Jawasa & Alhagi maurorum & Aerial part & 50 \\
\hline Kutaki & Picrorhiza kurroa & Root and stem & 50 \\
\hline Trayamana & Gentiana kurroo & Root & 50 \\
\hline Netrabala & Sida cardifolia & Root & 50 \\
\hline Neem Chaal & Azadirachta indica & Bark, leaf and seed & 50 \\
\hline Mulethi & Glycyrrhiza Glabra & Root & 50 \\
\hline Kuda chhal & Holarrhena Antidysenterica. & Seed and bark & 100 \\
\hline Ajwain & Trachyspermum ammi & Fruit & 50 \\
\hline Bharangi & Clerodendrum Serratum & Leaf and root & 100 \\
\hline Sahjan beej & Moringa oleifera & Seed & 50 \\
\hline Kiratatikta & Swertia chirayita & Whole plant extract & 50 \\
\hline Vacha (Bal) & Acorus Calamus, & Root & 50 \\
\hline Chitrak & Plumbago zeylanica. & Root & 50 \\
\hline Devdaru & Cedrus deodara & Bark & 50 \\
\hline
\end{tabular}




\begin{tabular}{|c|c|c|c|}
\hline Dravya & Scientific name & Part used & Amount (mg) \\
\hline Chavya & Piper retrofractum & Root and fruit & 50 \\
\hline Patolpatra & Richosanthes dioica & Leaf & 50 \\
\hline Kalmegh & Andrographis paniculata & Root & 100 \\
\hline Lavang & Syzygium aromaticum & Flower & 100 \\
\hline Kamal & Nelumbo nucifera Gaertn & Flower and rhizome & 100 \\
\hline Kakoli (tuber root) & Lilium polyphyllum $D$ & Flower and bulb & 50 \\
\hline Tejpatra & Cinnamomum Tamala & Leaf and bark & 50 \\
\hline Talispatra & Taxaceae & Leaf and bark & 50 \\
\hline Javitri & Myristica Fragrans & Seed & 50 \\
\hline Ativisha & Aconitum heterophyllum & Root & 100 \\
\hline Haldi & Curcuma longa & Root and stem & 50 \\
\hline Dalchini & Cinnamomum verum & Leaf and bark & 50 \\
\hline Khas & Chrysopogon zizanioides & Root & 50 \\
\hline Shwet Chandan & Santalum album & Root & 50 \\
\hline Khareti & Sida cordifolia Linn & Bark and seed & 50 \\
\hline Shaliparni & Desmodium gangeticum & Root & 100 \\
\hline Prishniparni & Uraria picta & Root, leaf & 100 \\
\hline
\end{tabular}

\section{Materials and Methods}

\subsection{Reagents.}

Endotoxin-lipopolysaccharide (LPS) derived from E. coli were procured from SigmaAldrich (St. Louis, USA). The PMN leucocytes were retrieved from the plasma sample of the protocol of healthy volunteers aged between 18-25 years was approved by Institutional Human Ethics Committee, Chitkara University, Punjab (IHEC/DHR/CU/PB/20/16). Milliplex kit, mouse macrophage cells (RAW264.7), Indomethacin, and polyinosinic-polycytidylic acid were procured from Sigma-Aldrich (St. Louis, USA). All the solvents, reagents, and chemicals used were of analytical grade.

\subsection{Animals.}

The study was conducted under the guidelines of CPCSEA and approved by Institutional Animals Ethical Committee, Chitkara College of Pharmacy, Chitkara University, Punjab under registration number 1181/PO/ReBi/S/08/CPCSEA. Inbreeding Wistar albino rats of both sexes (200-250 gm) were accommodated in appropriate facilities and habituated for a duration of 7 days prior to the initiation of experiments. The animals (Wistar rat) were freely accessed with feed and distilled water for $24 \mathrm{~h}$. Experimental animals were randomly divided into five groups of six rats each (three male and three female) for cytokine storm activity. The test group animals were treated with oral administration of $\mathrm{VL}^{\circledR}$-NS in $1.0 \mathrm{ml}$ distilled water, whereas the Vehicle/Control animals were given distilled water (p.o).

\subsection{Preparation of $V L^{\circledR}-N S$ formulation.}

The polyherbal powder formulation consisting of immunostimulant herbs $\left(\mathrm{VL}^{\circledR}-\mathrm{NS}\right)$ was manufactured using traditional herbs with data from traditional text and pharmacological studies for individual immunomodulatory and anti-inflammatory activity, by the standard powder formulation method (Table 1). The herbal ingredients were powdered separately, passed through 80 \# sieve, and mixed in ascending order with continuous trituration to get a homogeneous mixture. The herbal blend was further mixed with lactose (diluents) and magnesium stearate (lubricant) for appropriate flow properties for packaging as powders or as capsules as $\mathrm{VL}^{\circledR}$-NS formulation [36]. 


\subsection{Immunostimulant activity of $V L^{\circledR}-N S$.}

\subsubsection{In-vitro phagocytosis test.}

Immunomodulatory activity of $\mathrm{VL}^{\circledR}-\mathrm{NS}\left(5,10,20,50,100 \mathrm{mgml}^{-1}\right.$ suspension) was evaluated through the in-vitro phagocytosis test using PMN function test. Approximately $5 \mathrm{ml}$ peripheral venous blood was collected in a sterile heparinized tube from healthy volunteers as per standard procedures in a sterile heparinized tube. Neutrophils have been withdrawn by sedimentation with the gradient density of Ficoll Hypaque. The RBC-PMN pellet was precipitated by adding dextran. The supernatants comprising over 90 percent of PMN cells were retrieved, and the density of the cells was modified $\left(1 \times 10^{6}\right.$ cellsml $\left.{ }^{-1}\right)$ using MEM. Candida albicans $\left(1 \times 10^{6}\right.$ cellsml $\left.^{-1}\right)$ was utilized as a test microorganism. The PMN cells were blended with Candida albicans and incubated for one hour at $37^{\circ} \mathrm{C}$ under $5 \% \mathrm{CO}_{2}$ atmosphere, in the presence $\mathrm{VL}^{\circledR}$-NS (as 5, 10, 20, 50, $100 \mathrm{mgml}^{-1}$ suspensions). The control was the identical solution without VL®-NS. Subsequent to incubation, cytosmears were created, followed by fixation through methanol, stained by Giemsa, and examined via oil-immersion microscopic technique $(100 \times)$ to establish phagocytic activity. Approximately 100 neutrophils were examined to count the cells containing ingested microorganisms [37-43]. Phagocytosis parameters were calculated using the following equations.

$$
\begin{array}{ll}
\% \text { Phagocytosis }=\frac{\text { PMN cells with phagocytosis activity }}{\text { Total number of PMN cells }} \times 100 & \text { Equation } 1 \\
\text { Phagocytic index }=\frac{\text { Number of Candida albicans engulfed }}{\text { Total number of neutrophils }} & \text { Equation } 2
\end{array}
$$

2.4.2. In-vitro cytokine storm inhibitory activity of $\mathrm{VL}^{\circledR}-\mathrm{NS}$.

Cytokine production in mouse mononuclear macrophage leukemia cells (RAW264.7) in culture medium $\left[10 \%\right.$ fetal bovine serum, $100 \mathrm{Uml}^{-1}$ of penicillin and $100 \mu \mathrm{gml}^{-1}$ of Streptomycin in Dulbecco's Modified Eagle Medium (DMEM)] was measured through multiplex bead-based cytokine assay. The cells were treated with polyinosinic-polycytidylic acid [poly (I:C)] (control); poly (I:C) along with indomethacin (reference) and poly (I:C) along

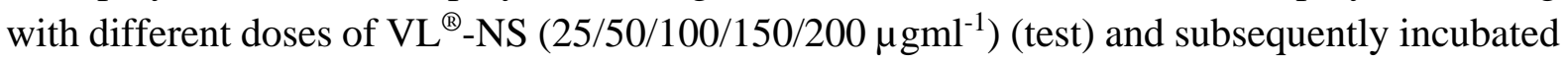
in $5 \% \mathrm{CO}_{2}$ incubator within a humidified atmosphere at $37^{\circ} \mathrm{C}$. After $24 \mathrm{~h}$ treatment, the interleukin-6 (IL-6); tumor necrosis factor- $\alpha$ (TNF- $\alpha$ ), and vascular endothelial growth factor (VEGF)] liberated from treated cells were calculated in supernatants of cell culture via Milliplex kit (Millipore, USA) [44-47].

2.4.3. In-vivo pharmacological activity.

\subsubsection{Treatment schedule for animals.}

$\mathrm{VL}^{\circledR}$-NS (250 and $500 \mathrm{mgkg}^{-1}$ body weight, p.o. twice daily) was administered to the test group animals for five days, and the vehicle was administered to control animals. The VL ${ }^{\circledR}$ NS was orally administered on each of two days before immunization, i.e., on the day of immunization and on each of two days following immunization (i.e., Days $-2,-1,0,+1,+2$ ). 


\subsubsection{Induction of LPS mediated cytokine storm activity.}

The rats were immunized by injecting endotoxin-lipopolysaccharide (LPS) derived from $E$. coli $\left(10 \mathrm{mgkg}^{-1}\right.$, i.p.). The $2^{\text {nd }}$ day after the immunization, blood samples were taken via retro-orbital puncture. After sampling, blood was immediately mixed with anticoagulant, followed by centrifugation to separate serum. After separating serum, samples were frozen until subsequent examination. All animals were breathing spontaneously during the experiments. For determination of interleukin-1 (IL-1), IL-6 and TNF- $\alpha$, ELISA kits were employed in accordance with the protocols provided by manufacturer Progenbiolab technologies, Delhi [48-51].

\subsubsection{Acute toxicity study of $\mathrm{VL}^{\circledR}-\mathrm{NS}$.}

The acute toxicity study of $\mathrm{VL}^{\circledR}$-NS was carried out in rats according to the recommended standards. Wistar rats $(n=3)$ were weighed before the commencement of the experiment. A single maximum tolerated dose $\left(2000 \mathrm{mgkg}^{-1}\right.$ p.o $)$ of $\mathrm{VL}^{\circledR}-\mathrm{NS}$ was given to test animals and monitored for mortality as well as changes in behavior over 14 days. Control animals were delivered distilled water [52].

\subsubsection{Calculation of human equivalent dose (HED) from animal dose.}

From the in-vivo pharmacological activity test in Wistar rats, an effective animal dose of $\mathrm{VL}^{\circledR}$-NS was determined. Subsequently, HED was calculated from animal dose using the following formula:

$$
\text { Human equivalent dose }\left(\frac{\mathrm{mg}}{\mathrm{kg}}\right)=\text { Animal dose }\left(\frac{\mathrm{mg}}{\mathrm{kg}}\right) \times\left[\frac{\text { Animal Weight }(\mathrm{kg})}{\text { Human Weight }(\mathrm{kg})}\right]^{0.33} \quad \text { Equation } 3
$$

\subsection{Statistical analysis.}

The reported findings are compiled from three separate trials and reflect a mean \pm standard deviation $(\mathrm{SD})$. Significant differences $(\mathrm{p}<0.05)$ were investigated by analysis of variance (ANOVA) and Dunnett test using GraphPad Prism version 6.01 (GraphPad Software, CA, USA).

\section{Results and Discussion}

\subsection{In-vitro phagocytosis test.}

Following drug particle or droplet deposition, particles must disperse within the fluids of epithelial cells. Physiologic factors, formulation of the drug as well as its physicochemical properties such as dissolution characteristics play an essential role in pulmonary drug dissolution. Slow dissolution as a rate-limiting step is obligatory as it prolongs lung retention, although with a simultaneous increase in the possibility that drug particles may get cleaned by mucociliary clearance.

$\mathrm{VL}^{\circledR}$-NS was evaluated at different concentrations of $5,10,20,50$, and $100 \mathrm{mgml}^{-1}$. It exhibited significant action at $100 \mathrm{mgml}^{-1}$ concentrations. The $\mathrm{VL}^{\circledR}-\mathrm{NS}$ tends to have phagocytosis capacity of ingesting foreign microbes, migration of neutrophils at the first stage of immune response indicating a key role in influencing the immune system. Neutrophil activation caused an increase in the innate cellular immune response. These findings of an invitro PMN function test revealed that phagocytosis, as well as phagocytic index for VL®-NS, 
augmented considerably (Figure 1). This indicated that $\mathrm{VL}^{\circledR}-\mathrm{NS}$ enhanced the phagocytic efficacy of the PMN cells at $100 \mathrm{mgml}^{-1}$ through elevated engulfment of Candida albicans in opposition to control, consequently inducing an unspecific immune system response. Since the $\mathrm{VL}^{\circledR}$-NS demonstrated hopeful immunostimulant behavior through in-vitro research, the therefore in-vivo animal investigation was conducted [37-43].

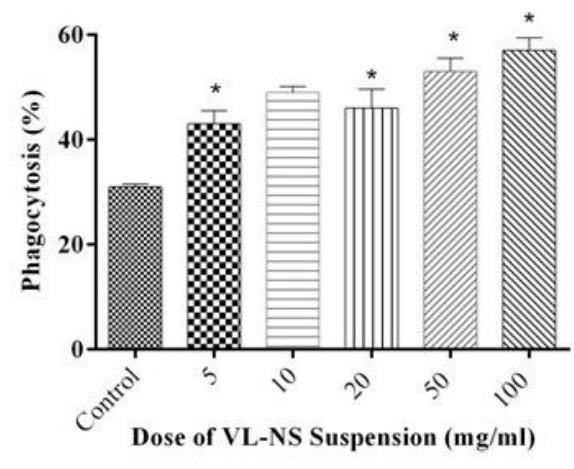

(a)

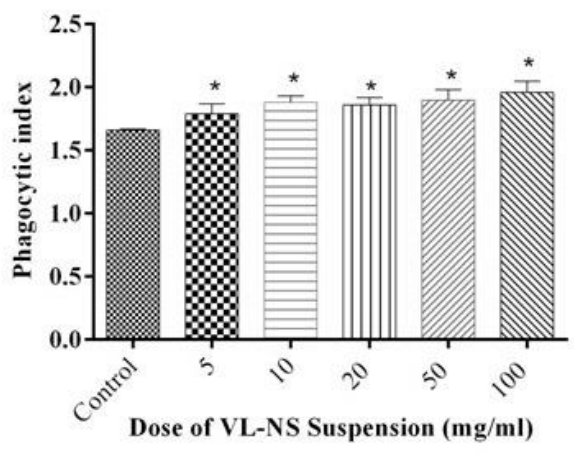

(b)

Figure 1. Effect of virulina ${ }^{\circledR}$-natural solutions $\left(\mathrm{VL}^{\circledR}\right.$-NS) on phagocytic efficacy of polymorphonuclear leucocytes. Results are presented as mean $\pm \mathrm{SD},(\mathrm{n}=3),{ }^{*} \mathrm{p}<0.05$ versus control.

\subsection{In-vitro cytokine storm inhibitory activity of $V L ®-N S$.}

Cytokines are a potent source of tiny proteins (5-20 kDa), which have been responsible for cell modulation as well as inflammation. The multiplex cytokine method was used to assess cytokine secretion in mouse mononuclear macrophage leukemia cells (RAW264.7) in a culture medium. Following $24 \mathrm{~h}$ incubation of cells with poly (I:C)/indomethcacin/VL ${ }^{\circledR}-\mathrm{NS}$, the cytokines discharged from cells were quantified by the Milliplex kit. The results revealed that $\mathrm{VL}^{\circledR}$-NS substantially lowered the overproduction of cytokines in poly (I: C)-induced RAW 264.7 cells by activation as well as normal T-cell expression (Figure 2) [44-47].

Viral \& bacterial pathogens disrupt the immunity function, which renders individuals across recurrent airway illnesses [47]. Viral infections cause type-1 interferon reactions through inducing targets for the identification of endosomal or cytosolic patterns, which are essential inflammatory initiators, i.e., cytokines [53,54]. This is widely established that viral \& bacterial illnesses tend to recurrent pathogenesis of extreme sepsis, which is marked through an intense synthesis of several inflammatory cytokines [55-58]. Sepsis remained a serious challenging issue with high death rates even after antibiotics. Since VL ${ }^{\circledR}-\mathrm{NS}$ herbal immunostimulant decreases cytokines levels; therefore, it could be explored for the management of viral and bacterial disorders in several clinical diseases [59-61]. Furthermore, in today's scenario, serious inflammatory reaction in various infections like cytomegalic, influenza, variola, corona, and avian H5N1 influenza viruses is believed to cause rigorous, unregulated cytokine development (cytokine storm). Therefore, it is crucial to concentrate on therapies that regulate the hyper-inflammation stimulated by viruses [62]. The current study revealed that $\mathrm{VL}^{\circledR}{ }^{\circledR} \mathrm{NS}$ ameliorated inflammatory response by lowering cytokines levels. Consequently $\mathrm{VL}^{\circledR}$-NS might be explored to attenuate hyper-inflammation associated with viruses. 


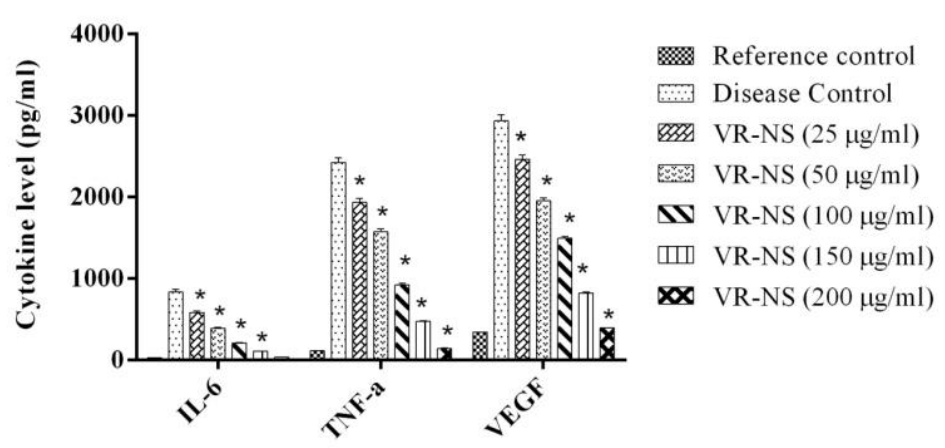

Figure 2. Effect of virulina ${ }^{\circledR}$-natural solutions $\left(\mathrm{VL}^{\circledR}-\mathrm{NS}\right)$ on cytokine levels in cytokine storm inhibitory activity in RAW264.7 cells. IL-6: Interleukin-6; TNF- $\alpha$ : tumor necrosis factor- $\alpha$; VEGF: vascular endothelial growth factor. $* \mathrm{p}<0.05$ versus control.

\subsection{In-vivo induction of LPS mediated cytokine storm activity.}

Serum cytokines levels are elevated in inflammatory diseases, bacterial \& viral infections. Tumor necrosis factor (TNF)- $\alpha$ and interleukins are important inflammatory mediators in sepsis conditions in the human body. In sepsis, these inflammatory responses are exacerbated by a cytokine storm that can lead to morbidity \& mortality. A dose-related rise in $48 \mathrm{~h}$ immune responses in rats occurred peroral delivery of 200 and $500 \mathrm{mg} / \mathrm{kg} \mathrm{VL}{ }^{\circledR}$-NS for 5 days. In Wistar rats, LPS induced tolerance leads to significant production of pro-inflammatory cytokines TNF- $\alpha$, IL-1, and IL-6, respectively, in comparison to the vehicle control group. Pre and post-treatment of rats with LPS challenge, VL ${ }^{\circledR}$-NS (200 and $500 \mathrm{mgkg}^{-1}$ ) significantly $(\mathrm{p}<0.05)$ dose dependably decrease the level of cytokines like TNF- $\alpha$, IL-1, and IL-6 as compared to the disease control group (Figure 3). Post-treatment with VL ${ }^{\circledR}$-NS effectively attenuated LPS-induced cytokine secretion. Interleukins reduce the secretion of proinflammatory cytokines and also lowers neutrophil infiltration induced by various antigens. This increase in the primary immune response to LPS asserted that perhaps the macrophages, as well as $\mathrm{T}$-and B-lymphocyte subgroups implicated in antibody production, are most responsive. VL ${ }^{\circledR}$-NS possibly promotes the proliferation of lymphocytes, which would, in turn, leads to cytokine synthesis, which activates certain immune cells like B-cells and several other T-cells. Across specific as well as non-specific immune pathways, $\mathrm{VL}^{\circledR}-\mathrm{NS}$ has been shown to have valuable immunostimulatory function [48-51].

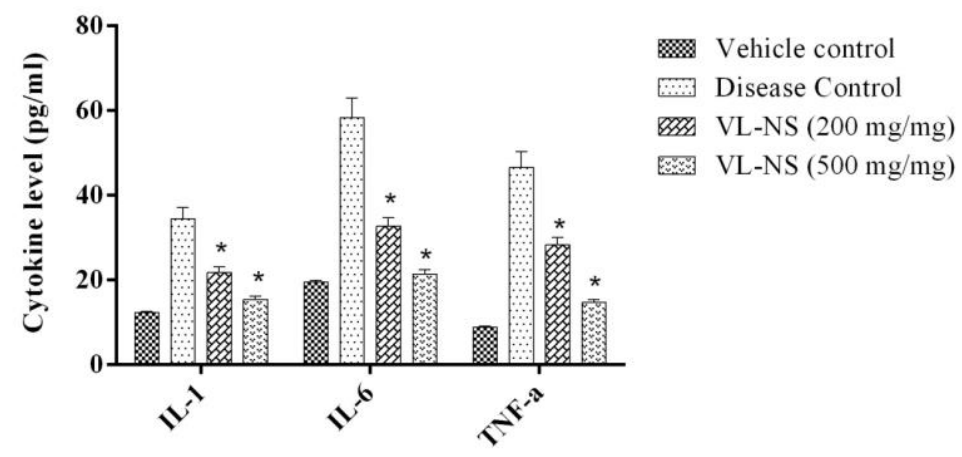

Figure 3. Effect of virulina ${ }^{\circledR}$-natural solutions $\left(\mathrm{VL}^{\circledR}{ }^{\circledR} \mathrm{NS}\right)$ on lipopolysaccharide mediated cytokine storm activity in Wistar rats. IL-1: interleukin-1; IL-6: interleukin-6; TNF- $\alpha$ : tumor necrosis factor- $\alpha$. Results are presented as mean \pm SEM, $(n=6), * p<0.05$ versus control. 


\subsection{Acute toxicity study of $V L^{\circledR}-N S$.}

Outcomes of a single-dose toxicity study revealed that VL ${ }^{\circledR}$-NS LD-50 was safe in Wistar rats [52]. Animals have shown no change in body weight when administrated at a dose level of $2000 \mathrm{mgkg}^{-1}$, p.o. No morbidity and behavioral changes have been observed in treated animals.

\subsection{Calculation of human equivalent dose (HED) from animal dose.}

The highest effective dose of $\mathrm{VL}^{\circledR}{ }^{\circledR}$-NS in Wistar rats during the in-vivo pharmacological test was found $500 \mathrm{mgkg}^{-1}$. Therefore, the estimated human equivalent dose of $\mathrm{VL}^{\circledR}-\mathrm{NS}$ calculated through the conversion factor was $4800 \mathrm{mg}$ per day.

\section{Conclusions}

Synthetic drugs have detrimental side effects, huge costs and are inadequate in controlling pathological facades of numerous disorders such as respiratory tract infections, chronic obstructive pulmonary disease, diabetes, and cancerous conditions. Therefore, in the present investigation, Virulina ${ }^{\circledR}$-Natural Solutions $\left(\mathrm{VL}^{\circledR}{ }^{\circledR}-\mathrm{NS}\right)$ polyherbal immunostimulant formulation consisting of several herbs was developed by the standard powder formulation method. VL ${ }^{\circledR}$-NS exhibited enhanced phagocytic efficacy at $100 \mathrm{mgml}^{-1}$, as estimated through the polymorphonuclear function test. VL ${ }^{\circledR}$-NS significantly reduced the excess production of cytokines in RAW264.7 macrophage cells, as estimated through multiplex cytokine assay. This polyherbal formulation demonstrated a decrease in cytokine storm activity in LPS tolerance animals at a dose of 200 and $500 \mathrm{mgkg}^{-1}$. In Wistar rats, no death or morbidity was observed in any animal that indicates its safety at the single maximum tolerated dose of VL ${ }^{\circledR}$-NS. No adverse effect was seen on the animals with respect to behavior, body weight, and lethargy. HED of VL ${ }^{\circledR}$-NS was found $4800 \mathrm{mg}$ per day. Conclusively, VL ${ }^{\circledR}-\mathrm{NS}$ immunostimulants have been considered as a superior and less toxic opportunity for the strengthening of the immune system for the management of several ailments.

\section{Funding}

This research received no external funding.

\section{Acknowledgments}

The authors express gratitude to Chitkara College of Pharmacy, Chitkara University, Punjab, India, for infrastructural support to carry out this research work.

\section{Conflicts of Interest}

The authors declare no conflict of interest.

\section{References}

1. Pressnall, M.M.; Huayamares, S.G.; Berkland, C.J. Immunostimulant complexed with polylysine limits transport and maintains immune cell activation. J. Pharm. Sci. 2020, 109, 2836-2846, https://doi.org/10.1016/j.xphs.2020.06.009.

2. Ji, J.; Merino, S.; Tomás, J.M.; Roher, N. Nanoliposomes encapsulating immunostimulants modulate the innate immune system and elicit protection in zebrafish larvae. Fish Shellfish Immunol. 2019, 92, 421-429, https://doi.org/10.1016/j.fsi.2019.06.016. 
3. Del-Rio-Navarro, B.E.; Espinosa, R.F.; Flenady, V.; Sienra-Monge, J.J. Immunostimulants for preventing respiratory tract infection in children. Cochrane Database Syst. Rev. 2006, 4, https://doi.org/10.1002/14651858.CD004974.pub2.

4. He, M.; Liu, G.; Liu, Y.; Yang, K.; Qi, X.; Huang, A.; Liu, T.; Wang, G.; Wang, E. Effects of geniposide as immunostimulant on the innate immune response and disease resistance in crucian carp. Aquaculture 2020, 529, https://doi.org/10.1016/j.aquaculture.2020.735713.

5. Eladl, A.H.; Mosad, S.M.; El-Shafei, R.A.; Saleh, R.M.; Ali, H.S.; Badawy, B.M.; Elshal, M.F. Immunostimulant effect of a mixed herbal extract on infectious bursal disease virus (IBDV) vaccinated chickens in the context of a co-infection model of avian influenza virus H9N2 and IBDV. Comp. Immunol. Microb. 2020, 72, https://doi.org/10.1016/j.cimid.2020.101505.

6. Mostbock, S. Cytokine/antibody complexes: An emerging class of immunostimulants. Curr. Pharm. Des. 2009, 15, 809-825.

7. Zhao, N.; Liu, C.; Zhu, C.; Dong, X.; Liu, X. Pidotimod: a review of its pharmacological features and clinical effectiveness in respiratory tract infections. Expert Rev. Anti-Infect. Ther. 2019, 17, 803-818, https://doi.org/10.1080/14787210.2019.1679118.

8. Elumalai, P.; Kurian, A.; Lakshmi, S.; Faggio, C.; Esteban, M. A.; Ring $\varnothing$, E. Herbal immunomodulators in aquaculture. Rev. Fish. Sci. Aquac. 2020, https://doi.org/10.1080/23308249.2020.1779651.

9. Khalaf, A.A.; Hussein, S.; Tohamy, A.F.; Marouf, S.; Yassa, H.D.; Zaki, A.R.; Bishayee, A. Protective effect of Echinacea purpurea (Immulant) against cisplatin-induced immunotoxicity in rats. DARU J. Pharm. Sci. 2019, 27, 233-241, https://doi.org/10.1007/s40199-019-00265-4.

10. Li, Y.; Pham, V.; Bui, M.; Song, L.; Wu, C.; Walia, A.; Zi, X. Rhodiola rosea L.: an herb with anti-stress, anti-aging, and immunostimulating properties for cancer chemoprevention. Curr. Pharmacol. Rep. 2017, 3, 384-395, https://doi.org/10.1007/s40495-017-0106-1.

11. Hamed, M.R.; Hassanein, N.M.A.; Zaquqe, S.A.M.; Mousa, A.A.R. Impact of certain immunomodulators on LPS-induced hematotoxicity. Med. Chem. Res. 2015, 24, 3283-3295, https://doi.org/10.1007/s00044015-1374-0.

12. Puggioni, F.; Alves-Correia, M.; Mohamed, M.F.; Stomeo, N.; Mager, R.; Marinoni, M.; Racca, F.; Paoletti, G.; Varricchi, G.; Giorgis, V.; Melioli, G.; Canonica, G.W.; Enrico Heffler, E. Immunostimulants in respiratory diseases: focus on Pidotimod. Multidiscip. Resp. Med. 2019, 14, https://doi.org/10.1186/s40248019-0195-2.

13. Wang, H.M.; Fu, L.; Cheng, C.C.; Gao, R.; Lin, M.Y.; Su, H.L.; Belinda, N.E.; Nguyen, T.H.; Lin, W.H.; Lee, P.C.; Hsieh, L.P. Inhibition of LPS-induced oxidative damages and potential anti-inflammatory effects of phyllanthus emblica extract via down-regulating NF- $\mathrm{B}, \mathrm{COX}-2$, and iNOS in RAW 264.7 Cells. Antioxidants 2019, 8, https://doi.org/10.3390/antiox8080270.

14. Shivaprasad, H.N.; Kharya, M.D.; Rana, A.C.; Mohan, S. Preliminary Immunomodulatory Activities of the Aqueous Extract of Terminalia chebula. Pharm. Biol. 2006, 44, 32-34. https://doi.org/10.1080/13880200500530542.

15. Kalmarzi, R.N.; Naleini, S.N.; Ashtary-Larky, D.; Peluso, I.; Jouybari, L.; Rafi, A.; Ghorat, F.; Heidari, N.; Sharifian, F.; Mardaneh, J.; Aiello, P. Anti-Inflammatory and immunomodulatory effects of Barberry (Berberis vulgaris) and its main compounds. Oxid. Med. Cell. Longev. 2019, 2019, https://doi.org/10.1155/2019/6183965.

16. Pandey, R.K.; Shukla, S.S.; Jain, A.; Jain, A.; Gupta, V.B.; Deb, L. Evaluation of comparative immunomodulatory potential of solanum xanthocarpum root and fruits on experimental animal. Indian J. Pharm. Educ. Res. 2018, 52, 237-245.

17. Carrasco, F.R.; Schmidt, G.; Romero, A.L.; Sartoretto, J.L.; Caparroz-Assef, S.M.; Bersani-Amado, C.A.; Cuman, R.K. Immunomodulatory activity of Zingiber officinale Roscoe, Salvia officinalis L. and Syzygium aromaticum L. essential oils: evidence for humor-and cell-mediated responses. J. Pharm. Pharmacol. 2009, 61, 961-967, https://doi.org/10.1211/jpp.61.07.0017.

18. Wang, P.; Yang, J.; Zhu, Z.; Zhang, X. Marsdenia tenacissima: a review of traditional uses, phytochemistry and pharmacology. Am. J. Chinese Med. 2018, 46, 1449-1480, https://doi.org/10.1142/S0192415X18500751.

19. Alsuhaibani, S.; Khan, M.A. Immune-stimulatory and therapeutic activity of Tinospora cordifolia: Doubleedged sword against salmonellosis. J. Immunol. Res. 2017, 2017, https://doi.org/10.1155/2017/1787803.

20. Hamedi, A.; Farjadian, S.; Karami, M.R. Immunomodulatory properties of Taranjebin (Camel's Thorn) manna and its isolated carbohydrate macromolecules. J. Evid. Based Complement Alternat. Med. 2015, 20, 269-274, https://doi.org/10.1177\%2F2156587215580490.

21. Hussain, A.; Shadma, W.; Maksood, A.; Ansari, S.H. Protective effects of Picrorhiza kurroa on cyclophosphamide-induced immunosuppression in mice. Pharmacogn. Res. 2013, 5, https://dx.doi.org/10.4103\%2F0974-8490.105646.

22. Rather, M.A.; Bhat, I.A.; Sharma, N.; Gora, A.; Ganie, P.A.; Sharma, R. Synthesis and characterization of Azadirachta indica constructed silver nanoparticles and their immunomodulatory activity in fish. Aquac Res. 2017, 48, 3742-3754, https://doi.org/10.1111/are.13199. 
23. Ayeka, P.A.; Bian, Y.; Githaiga, P.M.; Zhao, Y. The immunomodulatory activities of licorice polysaccharides (Glycyrrhiza uralensis Fisch.) in CT 26 tumor-bearing mice. BMC complement Alternat. Med. 2017, 17, https://doi.org/10.1186/s12906-017-2030-7.

24. Shruthi, R.R.; Venkatesh, Y.P.; Muralikrishna, G. Structural and functional characterization of a novel immunomodulatory glycoprotein isolated from ajowan (Trachyspermum ammi L.). Glycoconj. J. 2017, 34, 499-514, https://doi.org/10.1007/s10719-017-9771-x.

25. Juvekar, A.R.; Nachankar, R.S.; Hole, R.C.; Wakade, A.S.; Kulkarni, M.P.; Ambaye, R.Y. In vitro and in vivo immunomodulatory activity of aqueous extract of Clerodendrum serratum L. roots. Planta Medica. 2006, 72, https://doi.org/10.1055/s-2006-949887.

26. Chaudhary, A.K.; Ahmad, S.; Mazumder, A. Cedrus deodara (Roxb.) Loud.: A Review on its ethnobotany, phytochemical and pharmacological profile. Pharmacogn. J. 2011, 3, 12-17, https://doi.org/10.5530/pj.2011.23.2.

27. Nety, S.; Koley, K.M.; Chourasia, D.; Sharma, K.; Bhandeker, S.K. Study of Phytochemical and Immunomodulatory Activity of Methanolic Extract of Andrographis Paniculata in Broiler Birds. J. Anim. Res. 2018, 8, 27-31, http://dx.doi.org/10.30954/2277-940X.2018.00150.05

28. Dibazar, S.P.; Fateh, S.; Daneshmandi, S. Immunomodulatory effects of clove (Syzygium aromaticum) constituents on macrophages: in vitro evaluations of aqueous and ethanolic components. J. Immunotoxicol. 2015, 12, 124-131, https://doi.org/10.3109/1547691X.2014.912698.

29. Chaurasia, J.K.; Mishra, A.; Tripathi, Y.B. Immunomodulation property of hexane fraction of leaves of Cinnamomum tamala Linn. in rats. Cell Biochem. funct. 2010, 28, 454-460, https://doi.org/10.1002/cbf.1677.

30. Checker, R.; Chatterjee, S.; Sharma, D.; Gupta, S.; Variyar, P.; Sharma, A.; Poduval, T.B. Immunomodulatory and radioprotective effects of lignans derived from fresh nutmeg mace (Myristica fragrans) in mammalian splenocytes. Int. Immunopharmacol. 2008, 8, 661-669., https://doi.org/10.1016/j.intimp.2008.01.012.

31. Jantan, I.; Ahmad, W.; Bukhari, S.N.A. Plant-derived immunomodulators: an insight on their preclinical evaluation and clinical trials. Front Plant Sci. 2015, 6, https://doi.org/10.3389/fpls.2015.00655.

32. Gautam, S.C.; Gao, X.; Dulchavsky, S. Immunomodulation by curcumin. In: Molecular Targets and Therapeutic Uses of Curcumin in Health and Disease. Advances in experimental medicine and biology. Aggarwal, B.B.; Surh, Y.J.; Shishodia, S. (eds) The Springer, Boston, MA. Volume 595, 2007; pp. 321-341, https://doi.org/10.1007/978-0-387-46401-5_14.

33. Gupta, A.; Chaphalkar, S.R. Immunopharmacological screening of aqueous root extract of Santalum album. J. Herbmed Pharmacol. 2016, 5, 7-11.

34. Tekade, S.H.; Mode, S.G.; Waghmare, S.P. Effect of Asparagus racemosus, Sida cordifolia and Levamisole on immunological parameters in experimentally induced mmunosuppressed broilers. Vet. World. 2008, 1, 49.

35. Mishra, P.K.; Singh, N.; Ahmad, G.; Dube, A.; Maurya, R. Glycolipids and other constituents from Desmodium gangeticum with antileishmanial and immunomodulatory activities. Bioorg. Med. Chem. Lett. 2005, 15, 4543-4546, https://doi.org/10.1016/j.bmcl.2005.07.020.

36. Mohapatra, P.; Shirwaikar, A.; Aswatha Ram, H.N. Standardization of a polyherbal formulation. Phcog Mag. 2008, 4, 65-69.

37. Lu, T.; Porter, A.R.; Kennedy, A.D.; Kobayashi, S.D.; DeLeo, F.R. Phagocytosis and killing of staphylococcus aureus by human neutrophils. J. Innate Immun. 2014, 6, 639-649, https://doi.org/10.1159/000360478.

38. Ducusin, R.J.; Sarashina, T.; Uzuka, Y.; Tanabe, S.; Ohtani, M. Phagocytic response of bovine polymorphonuclear leukocytes to different incubation conditions and following exposure to some effectors of phagocytosis and different anticoagulants in vitro. Can. J. Vet. Res. 2001, 65, 38-44.

39. Bhattacharjee, B.; Singha, A.K.; Maiti, D. Phagocytic activity of neutrophil is induced by granulocyte colony stimulating factor and interleukin-15 in leukemic animal model. J. Cell. Immunother. 2016, 2, 52-57, https://doi.org/10.1016/j.jocit.2016.01.002.

40. Reiné, J.; Rylance, J.; Ferreira, D.M.; Pennington, S.H.; Welters, I.D.; Parker, R.; Morton, B. The whole blood phagocytosis assay: a clinically relevant test of neutrophil function and dysfunction in communityacquired pneumonia. BMC Res. Notes 2020, 13, https://doi.org/10.1186/s13104-020-05034-0.

41. Nfambi, J.; Bbosa, G.S.; Sembajwe, L.F.; Gakunga, J.; Kasolo, J.N. Immunomodulatory activity of methanolic leaf extract of Moringa oleifera in Wistar albino rats. J. Basic Clin. Physiol. Pharmacol. 2015, 26, 603-611, https://doi.org/10.1515/jbcpp-2014-0104.

42. Solanki, Y.B.; Jain, S.M. Immunostimolatory activities of Vigna mungo L. extract in male Sprague-Dawley rats. J. Immunotoxicol. 2010, 7, 213-218, https://doi.org/10.3109/15476911003792278

43. Eze, J.I.; Ekelozie, C.F.; Nweze, E.N. Immunomodulatory activity of Buchholzia coriacea seed methanol extract on Trypanosoma brucei brucei infected mice. Pharm Biol. 2017, 55, 636-640, https://doi.org/10.1080/13880209.2016.1265988. 
44. Chen, S.; Liu, G.; Chen, J.; Hu, A.; Zhang, L.; Sun, W.; Tang, W.; Liu, C.; Haiwei Zhang, H.; Ke, C.; Wu, J.; Chen, X. Ponatinib protects mice from lethal influenza infection by suppressing cytokine storm. Front Immunol. 2019, 10, https://doi.org/10.3389/fimmu.2019.01393.

45. Li, Y.; Hao, N.; Zou, S.; Meng, T.; Tao, H.; Ming, P.; Li, M.; Ding, H.; Li, J.; Shibin Feng, S.; Wang, X.; $\mathrm{Wu}, \mathrm{J}$. Immune regulation of RAW264.7 cells in vitro by flavonoids from astragalus complanatus via activating the NF- $\mathrm{B}$ signalling pathway. J. Immunol. Res. 2018, 2018, https://doi.org/10.1155/2018/7948068.

46. Tsai, M.H.; Chang, C.H.; Tsai, R.K.; Hong, Y.R.; Chuang, T.H.; Fan, K.T.; Peng, C.W.; Wu, C.Y.; Hsu, W.L.; Wang, L.S.; Chen, L.K.; Yu, H.S. Cross-regulation of pro-inflammatory cytokines by interleukin-10 and mir-155 in orientia tsutsugamushi-infected human macrophages prevents cytokine storm. J. Invest. Dermatol. 2016, 136, 1398-1407, https://doi.org/10.1016/j.jid.2015.11.034.

47. Cooper, P.R.; Lamb. R.; Day, N.D.; Branigan, P.J.; Kajekar, R.; San Mateo, L.; Hornby, P.J.; Panettieri, R.A. Jr. TLR3 activation stimulates cytokine secretion without altering agonist-induced human small airway contraction or relaxation. Am. J. Physiol. Lung Cell Mol. Physiol. 2009, 297, 530-537, https://doi.org/10.1152/ajplung.00133.2009.

48. Guo, F.; Yan, C.Y. Effect of SecinH3 on lung injury induced by sepsis of rats. Asian Pac. J. Trop. Med. 2015, 8, 1049-1054, https://doi.org/10.1016/j.apjtm.2015.11.004.

49. Kudo, K.; Hagiwara, S.; Hasegawa, A.; Kusaka, J.; Koga, H.; Noguchi, T. Cepharanthine exerts antiinflammatory effects via NF-кB inhibition in a LPS-induced rat model of systemic inflammation. J. Surg. Res. 2011, 171, 199-204, https://doi.org/10.1016/j.jss.2010.01.007.

50. Ishiguro, T.; Takeda, J.; Fang, X.; Bronson, H.; Olson, D.M. Interleukin (IL)-1 in rat parturition: IL-1 receptors 1 and 2 and accessory proteins abundance in pregnant rat uterus at term - regulation by progesterone. Comparative Study Physiol Rep. 2016, 4, https://doi.org/10.14814/phy2.12866.

51. Ramos-Benitez, M.J.; Ruiz-Jimenez, C.; Rosado-Franco, J.J.; Ramos-Pérez, W.D.; Mendez, L.B.; Osuna, A.; Espino, A.M. Fh15 Blocks the Lipopolysaccharide-Induced cytokine storm while modulating peritoneal macrophage migration and CD38 expression within spleen macrophages in a mouse model of septic shock. mSphere 2018, 3, e00548-18, https://doi.org/10.1128/mSphere.00548-18.

52. Ugwah-Oguejiofor, C.J.; Okoli, C.O.; Ugwah, M.O.; Umaru, M.L.; Ogbulie, C.S.; Mshelia, H.E.; Umar, M.; $\mathrm{Njan}, \mathrm{A}$.A. Acute and sub-acute toxicity of aqueous extract of aerial parts of Caralluma dalzielii N. E. Brown in mice and rats. Heliyon 2019, 5, https://doi.org/10.1016/j.heliyon.2019.e01179.

53. Smith, J.A. A new paradigm: Innate immune sensing of viruses via the unfolded protein response. Front Microbiol. 2014, 5, https://doi.org/10.3389/fmicb.2014.00222.

54. Mahima Ingle, A.M.; Verma, A.K.; Tiwari, R.; Karthik, K.; Chakraborty, S.; Deb, R.; Rajagunalan, S.; Rathore, R.; Dhama, K. Immunomodulators in day to day life: A Review. Pak. J. Biol. Sci. 2013, 16, 826843, https://doi.org/10.3923/pjbs.2013.826.843.

55. Kang, X.; Kim, H.J.; Ramirez, M.; Salameh, S.; Ma, X. The septic shock-associated IL-10-1082 A>G polymorphism mediates allele-specific transcription via poly(ADP-Ribose) polymerase 1 in macrophages engulfing apoptotic cells. J. Immunol. 2010, 184, 3718-3724, https://doi.org/10.4049/jimmunol.0903613.

56. Cammer, M.; Cox, D. Chemotactic responses by macrophages to a directional source of a cytokine delivered by a micropipette. Methods Mol. Biol. 2014, 1172, 125-135, https://doi.org/10.1007/978-1-4939-0928-5_11.

57. Medina, E.A.; Morris, I.R.; Berton, M.T. Phosphatidylinositol 3-Kinase activation attenuates the TLR2mediated macrophage pro-inflammatory cytokine response to Francisella tularensis live vaccine strain. $J$. Immunol. 2010, 185, 7562-7572, https://doi.org/10.4049/jimmunol.0903790.

58. Gabhe, S.Y.; Tatke, P.; Khan, T. Evaluation of the immunomodulatory activity of the methanol extract of Ficus benghalensis roots in rats. Ind. J. Pharmacol. 2006, 38, 271-275, https://doi.org/10.4103/02537613.27024.

59. Hu, Z.; Murakami, T.; Suzuki, K.; Tamura, H.; Kuwahara-Arai, K.; Iba, T.; Nagaoka, I. Antimicrobial cathelicidin peptide 11-37 inhibits the LPS/ATP-induced pyroptosis of macrophages by dual mechanism. PLoS ONE 2014, 9, 1-9, https://doi.org/10.1371/journal.pone.0085765.

60. Ulloa, L.; Tracey, K.J. The "cytokine profile": a code for sepsis. Trends Mol. Med. 2005, 11, 56-63, https://doi.org/10.1016/j.molmed.2004.12.007.

61. Wareing, M.D.; Lyon, A.B.; Lu, B.; Gerard, C.; Sarawar, S.R. Chemokine Expression during the development and resolution of a pulmonary leukocyte response to influenza A virus infection in mice. $J$. Leukoc. Biol. 2004, 76, 886-895, https://doi.org/10.1189/jlb.1203644.

62. Tisoncik, J.R.; Korth, M.J.; Simmons, C.P.; Farrar, J.; Martin, T.R.; Katze, M.G. Into the eye of the cytokine storm. Microbiol. Mol. Biol. Rev. 2012, 76, 16-32, https://doi.org/10.1128/MMBR.05015-11. 